\title{
In Vitro Studies on Alpha Amylase Inhibitory Activity of Some Indigenous Plants
}

\author{
Mangesh A Bhutkar*, Somnath D Bhinge, Dheeraj S Randive, Ganesh H Wadkar and Sachin S Todkar \\ Department of Pharmaceutics, Rajarambapu College of Pharmacy, India
}

*Corresponding author: Mangesh A Bhutkar, Assistant Professor, Department of Pharmaceutics, Rajarambapu College of Pharmacy, Kasegaon, TalWalwa, District Sangli, Maharashtra, 415404, India

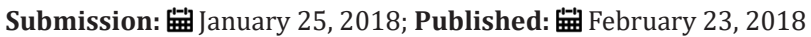

\begin{abstract}
Diabetes mellitus is a chronic metabolic disorder characterized by high blood glucose level caused due to deficiency of insulin secretion or insulin action. It includes a group of metabolic diseases characterized by hyperglycemia, in which blood sugar levels are elevated either because the pancreas do not produce enough insulin or cells do not respond to the produced insulin. Thus, a therapeutic approach to treat diabetes is to decrease postprandial hyperglycemia in patients with type II diabetes. It can be achieved by the inhibition of carbohydrate hydrolyzing enzymes like alpha amylase and alpha glucosidase. Such inhibitors which find application in the clinical practice for management of diabetes are known to be associated with various gastrointestinal side effects. Therefore, it is the need of time to identify and explore the amylase inhibitors from natural sources having fewer side effects. In the present study, aqueous extracts of selected plants namely Albizzia lebbeck, Berberis aristata, Mucuna pruriens, Myristica fragrans, Catharanthus roseus, and Caesalpinia bonducella which are used in the Ayurvedic traditional system of medicine to treat diabetes were tested for their inhibitory effect on $\alpha$-amylase. The results revealed that the extract of $A$. lebbeck at a concentration of $1000 \mu \mathrm{g} / \mathrm{ml}$ exhibited an inhibition of $70.91 \%$, whereas the extracts of B. aristata and M. pruriens showed an inhibition of $65.24 \%$ and $62.96 \%$ respectively at a similar concentration. The extracts of $C$. roseus, $M$. fragrans and $C$. bonducella exhibited a relatively less inhibitory response for the $\alpha$-amylase enzyme. The results of the work thus clearly indicate the potential of the studied extracts to manage hyperglycemia.
\end{abstract}

Keywords: Antidiabetic; $\alpha$-Amylase; Inhibitory effects; Indigenous plants

\section{Introduction}

Diabetes mellitus is a complex chronic metabolic disorder that has become a major source of ill health worldwide. It is characterized by hyperglycemia and disturbances of carbohydrate, protein and fat metabolisms, secondary to an absolute or relative lack of the hormone insulin [1-4]. Currently, the treatments of diabetes, in addition to insulin supplement includes many oral hypoglycemic agents such as sulfonylureas, biguanides, thiazolidines, D-phenylalanine derivatives, meglitinides and $\alpha$-glucosidase inhibitors along with appropriate diet and exercise. However, none of them can be considered to be an ideal one, due to their toxic side effects and sometimes reduction in response after long term use [5]. One of the therapeutic approaches useful for treatment of diabetes is to decrease the post-prandial hyperglycemia. It can be achieved by retarding the absorption of glucose through the inhibition of the carbohydrate hydrolyzing enzymes in the digestive tract. $\alpha$-amylase is an enzyme responsible for the breakdown of oligo and/or disaccharide to monosaccharides. Its inhibitors prolong the overall carbohydrate digestion time causing a marked decrease in the rate of glucose absorption thereby blunting the post prandial plasma glucose rise [6]. Acarbose, Miglitol and Voglibose are the typical examples of inhibitors used in the clinical practice [7]. However, the major drawbacks of these drugs include various gastrointestinal side effects such as abdominal pain, flatulence and diarrhea in the patients $[8,9]$. Thus, efforts are needed to identify and explore the amylase inhibitors from natural sources having fewer side effects.

Ayurveda and other ancient Indian literature have mentioned several herbal plants and their preparations useful in the treatment of various diseases and disorders [10-12]. Ethano pharmacological surveys have shown that more than 1200 plants have been mentioned in traditional medicine for their alleged hypoglycemic activity [13]. Numerous plants and their products have been widely prescribed and used for diabetic treatment all around the world with less known mechanistic basis of their functioning. The present study was therefore undertaken to make a comparative study for the ability of the selected plants to inhibit $\alpha$-amylase activity. The following plants were selected for the study namely, Albizzia lebbeck (AL), Berberis aristata (BA), Mucuna pruriens(MP), Myristica fragrans(MF), Catharanthus roseus (CR), and Caesalpinia bonducella (CB).

Albizzia lebbeck (Leguminosae) is a deciduous tree with medicinal uses. Barks and seeds are astringent, and are given in piles 
and diarrhea. Ethanolic extract of pods possesses antiprotozoal, hypoglycemic and anticancer properties [14,15].

Berberis aristata (Berberidaceae) have been studied for febrifugal, hypotensive, immunostimulating, anti-inflammatory, antidiabetic, antimicrobial, antiprotozoal, anticholinergic, antiarrhythmic, antiplasmodial, hypolipidemic, anti-granuloma and anti-hemolytic activity $[3,16,17]$.

Mucuna pruriens (Fabaceae) is one of the popular drugs in the Ayurvedic system of medicine [18]. Various preparations from the seeds of this plant are used for the management of several free radical mediated diseases such as ageing, rheumatoid arthritis, diabetes, atherosclerosis, male infertility and nervous disorders [15].

Myristica fragrans (Myristicaceae) has been known to possess cytotoxic, hepatoprotective, antioxidant, anti-inflammatory, antithrombotic, hypolipidaemic, antiatherosclerotic, hypoglycaemic and antidiabetic activities [19-21].

Catharanthus roseus (Apocynaceae) which is commonly known as 'periwinkle' and is an important source of indole alkaloids, which are present in all plant parts. It is used for the treatment of diabetes, fever, malaria, throat infections, and chest complaints. It is also used for the regulation of menstrual cycles, and as a euphoriant $[22,23]$.

Caesalpinia bonducella (Caesalpiniaceae) has been reported to exhibit wide array of activities including antidiabetic, adaptogenic, anthelmintic, antifilarial, antibacterial, antifungal, antispasmodic activity, antioxidant, antipsoriatic and antitumor activity [24-26].

Myristica fragrans (H.) (Myristicaceae) has been known to possess cytotoxic, hepatoprotective, antioxidant, antiinflammatory, antithrombotic, hypolipidaemic, antiatherosclerotic, hypoglycaemic and antidiabetic activities [27-29]. The present study thus aimed to make a comparative study for the ability of the extracts of selected plants to inhibit in-vitro $\alpha$-amylase activity.

\section{Materials and Methods}

\section{Chemicals and reagents}

All the chemicals used during the experimental work were of analytical grade obtained from S.D. Fine Chemicals Pvt. Ltd. Mumbai, Sigma chemical company, USA and Loba chemicals, Mumbai.

\section{Plant material}

The seeds of $M$. pruriens, and $C$. bonducella were collected from local areas of Kasegaon, District Sangli, (MS), India, whereas the seeds of $M$. fragrans and roots of $B$. aristata were purchased from the local market. Bark of $A$. lebbeck and roots of $C$. roseus were collected from local areas of Karad, District Satara, (MS), India. The plant material was further identified and authenticated by the Department of Botany, YC College of Science, Karad. The plant material was cleaned thoroughly, dried in a hot air oven $\left(50^{\circ} \mathrm{C}\right)$ separately powdered, passed through 60 mesh sieve (BS) and thereafter stored in an airtight container at $4^{\circ} \mathrm{C}$ till further use.

\section{Preparation of plant extracts}

Aqueous extracts were prepared by extracting the powders of the plant materials with hot water $\left(70^{\circ} \mathrm{C}\right)$ in a mechanical shaker (24h), filtered and freeze dried.

\section{Assay for $\alpha$-amylase inhibition [30]}

In this method $1 \mathrm{ml}$ substrate- potato starch $(1 \% \mathrm{w} / \mathrm{v}), 1 \mathrm{ml}$ of drug solution (Acarbose, std drug/ plant extracts) of four different concentration such as $250,500,750$ and $1000 \mu \mathrm{g} / \mathrm{ml}, 1 \mathrm{ml}$ of alpha amylase enzyme $(1 \% \mathrm{w} / \mathrm{v})$ and $2 \mathrm{ml}$ of acetate buffer $(0.1 \mathrm{M}, 7.2 \mathrm{pH})$ were mixed together. These solutions were prepared using acetate buffer $(820.3 \mathrm{mg}$ Sodium acetate and $18.7 \mathrm{mg}$ sodium chloride in $100 \mathrm{ml}$ distilled water).The above mixture was incubated for $1 \mathrm{hr}$. Then $0.1 \mathrm{ml}$ of iodine-iodide indicator $(635 \mathrm{mg}$ Iodine and $1 \mathrm{gm}$ potassium iodide in $250 \mathrm{ml}$ distilled water) was added in the mixture. Absorbance of the resulting solution was measured at $565 \mathrm{~nm}$ using UV-Visible spectrophotometer.

$$
\% \text { inhibition }=\frac{A s-A c}{A s} \times 100
$$

Where Ac is the absorbance of the control and As is the absorbance of the sample.

\section{Statistical analysis}

All the analyses were carried out in triplicate and the results were expressed in mean \pm SD.

\section{Results and Discussion}

Many herbal extracts has been reported for their antidiabetic activities and being used in the traditional system of medicine, Ayurveda for the treatment of diabetes. Numerous herbal extracts have been investigated with respect to suppression of glucose production from carbohydrates in the gut or glucose absorption from the intestine. The enzyme alpha amylase catalyses the hydrolysis of 1,4-glucosidic linkages of starch, glycogen and various oligosaccharides into simpler sugars which can be readily available for the intestinal absorption. Inhibition of alpha amylase enzyme in the digestive tract of human is being considered to be effective in controlling diabetes by decreasing the absorption of glucose from starch. However, medicinal plants have not gained much importance as medicines and one of the vital factors is lack of specific standards being prescribed for herbal medicines and scientific support. Thus, the study was undertaken to assess the inhibitory action of the selected plant extracts on the alpha amylase enzyme.

Aqueous extracts of different parts of selected plants with known antidiabetic activity were investigated for their potential to inhibit $\alpha$-amylase activity at five different concentrations viz. $100 \mu \mathrm{g} / \mathrm{ml}, 250 \mu \mathrm{g} / \mathrm{ml}, 500 \mu \mathrm{g} / \mathrm{ml}, 750 \mu \mathrm{g} / \mathrm{ml}$ and $1000 \mu \mathrm{g} / \mathrm{ml}$. The results of inhibition of alpha amylase enzyme by the selected plant extracts have been represented in Figure 1. It was observed that the selected plants showed exhibited variable inhibitory effects on $\alpha$-amylase activity in vitro. Acarbose was used as a standard for this activity. The extract of $A$. lebbeck at a concentration of $1000 \mu \mathrm{g} /$ $\mathrm{ml}$ exhibited an inhibition of $70.91 \%$, whereas the extracts of $B$. aristata and M. pruriens showed an inhibition of $65.24 \%$ and 62.96 
$\%$ respectively at a similar concentration. Acarbose exhibited the inhibition of $81.48 \%$ at a concentration of $1000 \mu \mathrm{g} / \mathrm{ml}$. The results of the assay are presented in the Table 1.

Table 1: Percentage inhibition of the enzyme alpha amylase by the selected plant extracts.

\begin{tabular}{|c|c|c|c|c|c|c|c|c|}
\hline $\begin{array}{c}\text { Concentration } \\
(\boldsymbol{\mu g} / \mathbf{m l})\end{array}$ & Acarbose & AL & BA & MP & MF & CR & CB \\
\cline { 2 - 8 } \% Inhibition \\
\hline 100 & 27.37 & 21.21 & 9.09 & 10.34 & 5.1 & 3.7 & 11 \\
\hline 250 & 45.14 & 38.96 & 30.1 & 25.71 & 10.34 & 7.14 & 15.03 \\
\hline 500 & 65.14 & 57.65 & 52.38 & 50.19 & 19.25 & 16.66 & 23.52 \\
\hline 750 & 72.39 & 64.08 & 58.06 & 57.65 & 23.52 & 18.75 & 27.37 \\
\hline 1000 & 81.48 & 70.91 & 65.24 & 62.96 & 28.96 & 23.07 & 34.01 \\
\hline
\end{tabular}

Acarbose showed an $\mathrm{IC}_{50}$ value of $383.7 \mu \mathrm{g} / \mathrm{ml}$ whereas the extracts of $A$. lebbeck, B. aristata and M. pruriens showed the inhibition of the alpha amylase enzyme at an $\mathrm{IC}_{50}$ value of $433.65 \mu \mathrm{g}$, $477.28 \mu \mathrm{g}$ and $498.10 \mu \mathrm{g}$ respectively. The extracts of C. roseus, M. fragrans and C. bonducella exhibited a relatively less inhibitory response for the $\alpha$-amylase enzyme. The results of the assay are presented in the Table 1 . The $\mathrm{IC}_{50}$ values are as shown in the Figure 2.

The outcomes of this study exhibited the alpha amylase inhibitory effects of the extracts of Albizzia lebbeck, Berberis aristata, Mucuna pruriens, Myristica fragrans, Catharanthus roseus, and Caesalpinia bonducella at five different concentrations viz. $100 \mu \mathrm{g} /$ $\mathrm{ml}, 250 \mu \mathrm{g} / \mathrm{ml}, 500 \mu \mathrm{g} / \mathrm{ml}, 750 \mu \mathrm{g} / \mathrm{ml}$ and $1000 \mu \mathrm{g} / \mathrm{ml}$. However, the inhibitory effect showed by the extracts of Albizzia lebbeck, Berberis aristata, Mucuna pruriens was more than the extracts of Myristica fragrans, Catharanthus roseus, and Caesalpinia bonducella at a similar concentration. The present study thus, indicated that the extracts of Albizzia lebbeck, Berberis aristata and Mucuna pruriens could be useful in the management of postprandial hyperglycemia. The results of this study directs further researches to evaluate the therapeutic potentialities of these extracts in the management of postprandial hyperglycemia and Type 2 diabetes either alone or in a combinatorial therapy (Figure $1 \& 2$ ).

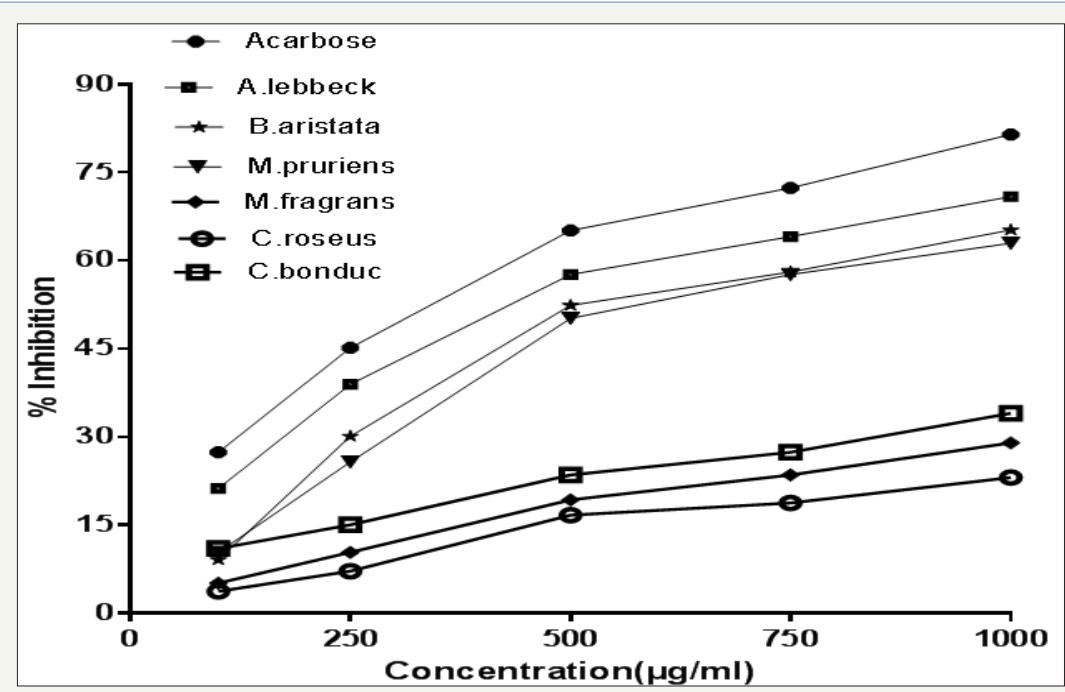

Figure 1: Inhibition of alpha amylase enzyme by Acarbose and selected plant extracts.

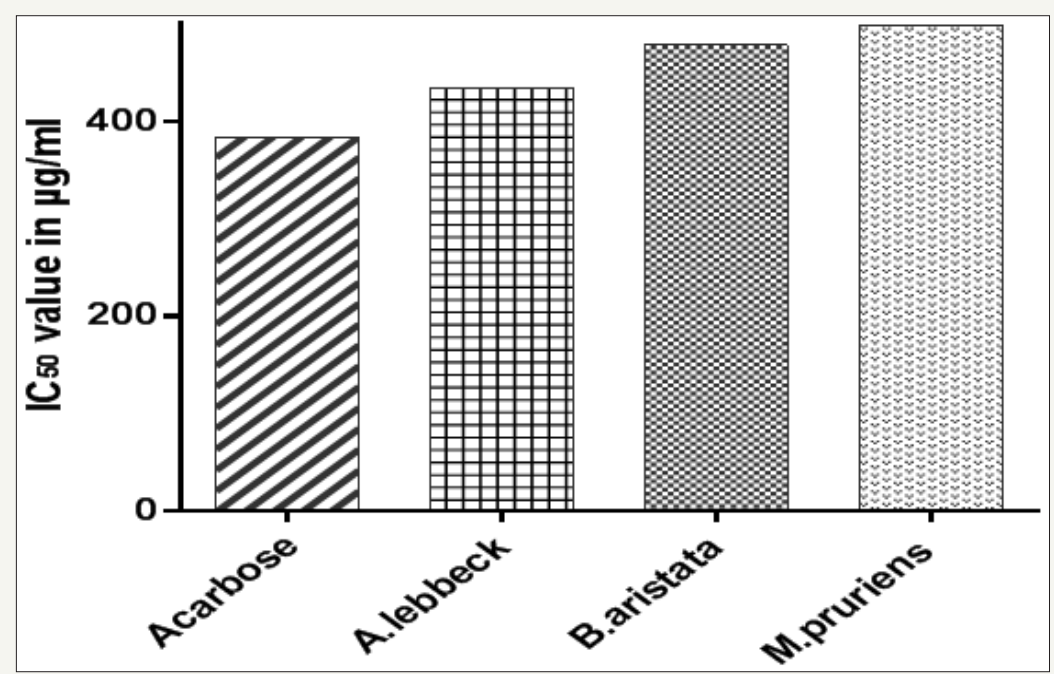

Figure 2: $\mathrm{IC}_{50}$ values of the plant extracts for alpha amylase inhibitory activity. 


\section{Conclusion}

The results of the present study indicate that the selected plant extracts exhibited maximum alpha amylase inhibitory activity and thus, will prove to be beneficial to reduce the rate of digestion and absorption of carbohydrates and thereby contribute for effective management of diabetes by decreasing the post-prandial hyperglycemia. The plants may essentially contain herbal bioactive compounds inhibiting enzyme activity and further structural elucidation and characterization methodologies have to be carried out in order to identify the bioactive constituents.

\section{References}

1. Alberti KG, Zimmet PZ (1998) New diagnostic criteria and classification of Diabetes-again? Diabetic Medicine 15(7): 535-536.

2. Bhutkar MA, Bhise SB (2013) Studies on antiglycation potential of some traditional antidiabetic plants, Asian J Plant Sci Res 3(6): 60-63.

3. Bhutkar MA, Bhinge SD, Randive DS, Wadkar GH (2017) Hypoglycemic effects of Berberis aristata and Tamarindus indica extracts in vitro. Bulletin of Faculty of Pharmacy, Cairo University 55(1): 91-94.

4. Bhutkar MA, Bhinge SD, Randive DS, Wadkar GH, Todkar SS (2017) Studies on in-vitro antiglycation potential of some indigenous antidiabetic plants. Glob J Pharmaceu Sci 3(5): 1-4.

5. Chattopadhyay RR (1999) A comparative evaluation of some blood sugar lowering agents of plant origin. J Ethnopharmacol 67(3): 367-372.

6. Rhabasa L, Chiasson JL (2004) Alpha-Glucosidase Inhibitors. Volume 1, ( $3^{\text {rd }}$ edn), John Wiley \& Sons Ltd, UK, pp. 901-904.

7. Bailey CJ (2003) New Approaches to the Pharmacotherapy of Diabetes. Volume 2, ( $3^{\text {rd }}$ edn), Blackwell Science Ltd., UK, pp. 73.1-73.21.

8. Fujisawa T, Ikegami H, Ogihara T, Inoue K, Kawabata Y (2005) Effect of two alpha-glucosidase inhibitors, voglibose and acarbose, on postprandial hyperglycemia correlates with subjective abdominal symptoms. Metabol 54(3): 387-390.

9. Singh SK, Rai PK, Jaiswal D, Watal G (2007) Evidence-based Critical Evaluation of Glycemic Potential of Cynodon dactylon. Evid Based Complement Alternat Med 5(4): 415-420.

10. Randive DS, Bhinge SD, Sayyad SF, Wadkar GH, Bhutkar MA (2016) Comparative standardization of marketed formulations of fermented biomedicine-Arjunaristha. Indonesian Journal of Pharmacy 27(4): 220225.

11. Randive DS, Sayyad SF, Bhinge SD, Bhutkar MA (2016) Preparation of Arjunarishta using microbes isolated from Woodfordia fruticosa flowers (Dhayati). Anc Sci Life 36(1): 42-47.

12. Grover JK, Yadav S, Vats V (2002) Medicinal plants of India with antidiabetic potential. J Ethnopharmacol 81(1): 81-100.

13. Pranav K, Doble M (2008) A target based therapeutic approach towards Diabetes mellitus using medicinal plants. Curr Diabetes Rev 4(4): 291308.

14. Rahul C, Lincy J, Methew G, Pradhan P (2010) Pharmacognostic standardization and phytochemical screening of Albizzia lebbeck. J Chem Pharm Res 2(1): 432-443.
15. Bhutkar MA, Bhise SB (2013) In vitro hypoglycemic effects of Albizzia lebbeck and Mucuna pruriens. Asian Pacific Journal of Tropical Biomedicine 3(11): 866-870.

16. Patel DK, Patel K, Dhanbal SP (2012) Standardization of Berberis aristata extract through conventional and modern HPTLC techniques. Asian Pacific Journal of Tropical Disease 2(Supplement 1): S136-S140.

17. Chandel S, Bagai U, Semwal RB, Semwal DK (2015) Antiplasmodial activity of aqueous extract of Berberis aristata roots against Plasmodium berghei-infected BALB/c mice. Pharm Biol 53(12): 1735-1740.

18. Sharma BK, Shamim A, Singh R (2012) A review on M. pruriens its phyto constituents and therapeutic uses. Novel Sci Int J Pharm Sci 1(6): 308312 .

19. Moteki H, Usami M, Katsuzaki H, Imai K, Hibasami H, et al. (2002) Inhibitory effects of spice extracts on the growth of human lymphoid leukaemia, Molt 4B cells. Japanese Society for Food Science and Technology 49: 688-691.

20. Morita T, Jinno K, Kawagishi H, Arimoto Y, Suganuma H, et al. (2003) Hepatoprotective effect of myristicin from nutmeg (Myristica fragrans) on lipopolysaccharide/d-galactosamine- induced liver injury, J Agric Food Chem 51(6): 1560-1565.

21. Dorman HJD, Surai P, Deans SG (2000) In vitro antioxidant activity of a number of plant essential oils and phytoconstituents. Journal of Essential Oil Research 7(6): 241-248.

22. Mishra P, Uniyal GC, Sharma S (2001) Pattern of diversity for morphological and alkaloid yield related trades among the periwinkle Catharanthus roseus accessions collected from in and around Indian Subcontinent. Genetic Res Crop Evol 48: 273-286.

23. Bhutkar MA, Bhise SB (2011) Comparative studies on antioxidant properties of Catharanthus rosea and Catharanthus alba. Int J Pharm Tech Res 3(3): 1551-1556.

24. Kannur DM, Hukkeri VI, Akki KS (2006) Antidiabetic activity of Caesalpinia bonducella seed extracts in rats. Fitoterapia 77(7-8): 546549.

25. Kannur DM, Hukkeri VI, Akki KS (2006) Adaptogenic activity of Caesalpinia bonduc seed extracts in rats. Journal of Ethnopharmacology 108(3): 327-331.

26. Gaur RL, Sahoo MK, Dixit S, Fatma N, Rastogi S, et al. (2008) Antifilarial activity of Caesalpinia bonducella against experimental filarial infections, Indian J Med Res 128(1): 65-70.

27. Morita T, Jinno K, Kawagishi H, Arimoto Y, Suganuma H, et al. (2003) Hepatoprotective effect of myristicin from nutmeg (Myristica fragrans) on lipopolysaccharide/d-galactosamine- induced liver injury. J Agric Food Chem 51(6): 1560-1565.

28. Dorman HJD, Surai P, Deans SG (2000) In vitro antioxidant activity of a number of plant essential oils and phytoconstituents. Journal of Essential Oil Research 7(6): 241-248.

29. Olajide OA, Makinde JM, Awe SO (2000) Evaluation of the pharmacological properties of nutmeg oil in rats and mice. Pharmaceutical Biology 38(5): 385-390.

30. Kotwaroo I, Mahomoodally MF, Gurib FA, Subratty AH (2006) Effects of Arthocarpus heterophyllus on $\alpha$-amylase activity in vitro. Phytotherapy Research 20(3): 228-231. 
(c) (i) Creative Commons Attribution 4.0 International License

For possible submissions Click Here

Submit Article
Your subsequent submission with Crimson Publishers

\section{will attain the below benefits}

- High-level peer review and editorial services

- Freely accessible online immediately upon publication

- Authors retain the copyright to their work

- Licensing it under a Creative Commons license

- Visibility through different online platforms

- Global attainment for your research

- Article availability in different formats (Pdf, E-pub, Full Text)

- Endless customer service

- Reasonable Membership services

- Reprints availability upon request

- One step article tracking system 